REPORTS OF MORPHOLOGY
$\begin{gathered}\text { Official Journal of the Scientific Society of Anatomists, } \\ \text { Histologists, Embryologists and Topographic Anatomists } \\ \text { of Ukraine } \\ \text { journal homepage: https://morphology-journal.com }\end{gathered}$

\title{
General craniometric characteristics of linear parameters of the middle cranial fossa of a mature person
}

Chekanova I.V.', Vovk O.Yu. ${ }^{1}$ Ikramov V.B. ${ }^{1}$, Dubina S.O.

${ }^{1}$ Kharkiv National Medical University, Kharkiv, Ukraine

${ }^{2}$ Donetsk National Medical University, Kramatorsk, Ukraine

\section{ARTICLE INFO}

Received: 7 September, 2020

Accepted: 15 October, 2020

UDC: $611.714 .06-053.8: 572.71$

\section{CORRESPONDING AUTHOR}

e-mail: vovkoleg80@gmail.com Vovk O.Yu.

\begin{abstract}
Given the rapid development of neurology, neurosurgery, otolaryngology and forensic medicine, there is a need for new, updated morphological data of internal base of the skull, in particular middle cranial fossa. This is due to the complex bone architecture of the middle cranial fossa and the location of important neurovascular structures in this area, which are important for surgeons not to damage during the operation. In this regard, it is necessary to detail the features of the structure, shape, position and size of the middle cranial fossa. The aim of the work is a detailed morphological and craniometric study of the linear parameters of the middle cranial fossa of a mature person depending on gender. The study was performed by studying 50 CT scans of the head and 50 bone preparations of the skulls of men and women of mature age. In our study, a detailed morphometry of longitudinal and latitudinal parameters at different levels of the middle cranial fossa, as well as determining its depth and area. Morphometry of linear parameters of the studied area of the skull showed the presence of a range of variability in length, width and depth depending on the sex of a mature person. The study showed an increase in the longitudinal size of the middle cranial fossa from the lateral to the medial; the transverse dimensions of the middle cranial fossa take on smaller values in its anterior parts and gradually increase to the posterior ones, which in our opinion is due to the characteristic shape of this part of the skull. The performed morphometry of longitudinal and latitudinal parameters, depth and area of the middle cranial fossa showed that these parameters are predominant in males in contrast to females, which is due to the slightly increased head size in this group of adult's people. Depth of the middle cranial fossa depth has the smallest range of variability depending on sex. It is established that right-handed asymmetry is more often observed in mature people of both sexes. Rarely, left-sided asymmetry is determined due to an increase in the length of the lateral sections in mature men. The data obtained make it possible to expand knowledge about the structure of the middle cranial fossa and can serve as a basis for further research.
\end{abstract}

Keywords: craniometry, mature age, internal base of the skull, middle cranial fossa.

\section{Introduction}

It is known that the middle cranial fossa (MCF) is one of the most complex parts of the inner base of the skull (IBS), which is limited in front by the posterior edge of the lesser wings of the sphenoid bone, behind - the back of the Sella turcica (ST) and petrous part of the temporal bone [6, 25].

In surgical practice, access to the MCF and the base of the skull is often performed in order to treat a large number of pathological processes [2, 4, 14, 15, 16, 18, 24]. Given the rapid development of neurology, neurosurgery, otolaryngology and forensic medicine, there is a need for new, updated morphological data of IBS, in particular MCF
$[5,10,11,17,20,22]$. This is due to the complex bone architecture of the MCF and the location of important vascular and nervous structures in this area, which are extremely important for surgeons not to damage during surgery. In this regard, it is necessary to modern detail of the structure, shape, position and size of the MCF, which will reduce the number or avoid complications during and after surgery within this area of IBS [8, 9, 19, 21, 23, 26].

The aim of this work is a detailed morphological and craniometric study of linear parameters of the middle cranial fossa of a mature person depending on sex. 


\section{Materials and methods}

The study was performed within the research work of the Department of Human Anatomy, Kharkiv National Medical University "Individual anatomical variability of craniotopographic features and spatial relationships of human head in the post-embryonic period of ontogenesis" № state registration $0118 \mathrm{U} 000954$.

The study was performed by examining 50 CT scans of the head and 50 bone preparations of the skulls of mature age men and women.

Craniometric examination of the MCF on craniotomograms of mature people was performed using the anatomical imaging system Anatomage table, with the installed program Launching Table 6.0 Application. Measurement of linear parameters of the MCF on bone preparations of the human skull was performed according to standard craniological methods, using a conventional set of measuring instruments. During the study, a detailed morphometry of longitudinal and transverse parameters of the MCF (Fig. 1), as well as determining its depth and area.

Variation statistics of the obtained data of complex measurements with calculation of arithmetic mean $(\bar{x})$, standard deviation $(\sigma)$ and mean error $(m)$ are carried out. Statistical analysis of the obtained quantitative data was performed using application packages "SPSS 7.0" and Excel from MS Office XP. The statistical significance of the obtained data was evaluated according to the Mann-Whitney test. The comparison results were considered plausible at $p \leq 0.05$.

\section{Results}

Given the rather complex form of MCF, it is important to study the basic craniometric linear parameters of MCF in mature men and women. Thus, we have established ranges of longitudinal and latitudinal parameters, depth and area dimensions in general and from both halves of the MCF depending on the sex.

It is determined that there is a certain range of longitudinal parameters of the MCF in mature age (Table 1).

It is established that the length from the most protruding point of the lesser wings of the sphenoid bone to the opposite point of the stony part of the temporal bone $\left(L_{1}\right)$ in men of the left part of the MCF reaches $\bar{x} \pm \sigma=71.41 \pm$ $5.14 \mathrm{~mm}$ and the right $-\bar{x} \pm \sigma=71.04 \pm 5.37 \mathrm{~mm}$. The length of the lateral sections of $L_{1}$ in mature women from the left and right part of the studied area of IBS varies between $\bar{x} \pm \sigma=68.04 \pm 5.76 \mathrm{~mm}$ and $\bar{x} \pm \sigma=68.59 \pm 5.25 \mathrm{~mm}$, respectively. It is known that this parameter is used in the calculation of the transverse-longitudinal index of the MCF.

In adult males and females, the total length $\left(L_{2}\right)$ of the left part of the left MCF is within $\bar{x} \pm \sigma=55.76 \pm 5.02 \mathrm{~mm}$ and

Table 1. Variation and statistical indicators of longitudinal craniometric dimensions of the MCF in mature persons $(\mathrm{mm})$.

\begin{tabular}{|c|c|c|c|c|c|c|}
\hline Investigated signs & $\min$ & $\max$ & $\overline{\mathrm{x}}$ & $\sigma$ & $\mathrm{m}$ \\
\hline \multirow{6}{*}{ Left } & Men & 61.4 & 81.0 & 71.41 & 5.14 & 0.73 \\
\cline { 2 - 7 } & Women & 59.0 & 83.0 & $68.04^{*}$ & 5.76 & 0.81 \\
\hline \multirow{2}{*}{ Right } & Men & 61.7 & 82.0 & 71.04 & 5.37 & 0.77 \\
\cline { 2 - 7 } & Women & 59.7 & 81.0 & $68.59^{* *}$ & 5.25 & 0.74 \\
\hline \multirow{7}{*}{ Left } & Men & 44.8 & 65.0 & 55.76 & 5.02 & 0.72 \\
\cline { 2 - 7 } & Women & 42.9 & 64.0 & $53.34^{* *}$ & 4.82 & 0.63 \\
\hline \multirow{2}{*}{ Right } & Men & 46.7 & 65.0 & 56.28 & 4.57 & 0.65 \\
\cline { 2 - 7 } & Women & 42.6 & 65.0 & $53.50^{*}$ & 4.48 & 0.63 \\
\hline \multirow{7}{*}{ Left } & Men & 18.2 & 28.0 & 23.45 & 2.31 & 0.34 \\
\cline { 2 - 7 } & Women & 18.0 & 30.0 & $22.26^{* *}$ & 2.64 & 0.39 \\
\hline \multirow{2}{*}{ Right } & Men & 17.9 & 28.0 & 23.77 & 2.51 & 0.37 \\
\cline { 2 - 7 } & Women & 17.7 & 33.0 & $22.33^{*}$ & 2.95 & 0.43 \\
\hline
\end{tabular}

Notes: *- a significant difference compared to men at $\mathrm{p}<0.01 ;{ }^{* *}$ a significant difference compared to men at $p<0.05$.

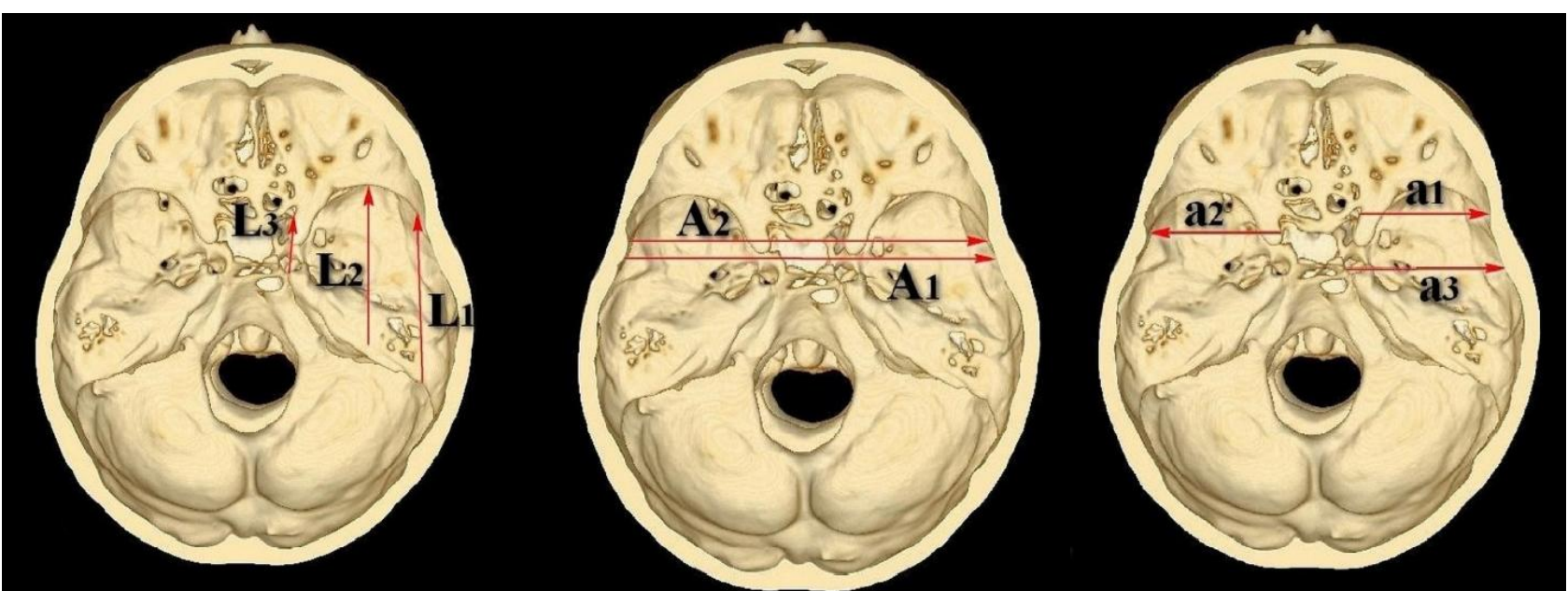

Fig. 1. Determination of MCF length distances in mature people on CT scans of the head: L1 - length of lateral departments, L2 - total length, L3 - length of the medial department, A1 - total width at the level of the sella turcica back, A2 - the total width at the level of the sella turcica tuber, a1 - front width, a2 - width at the level of the sella turcica tuber, a3 - rear width (mm). 


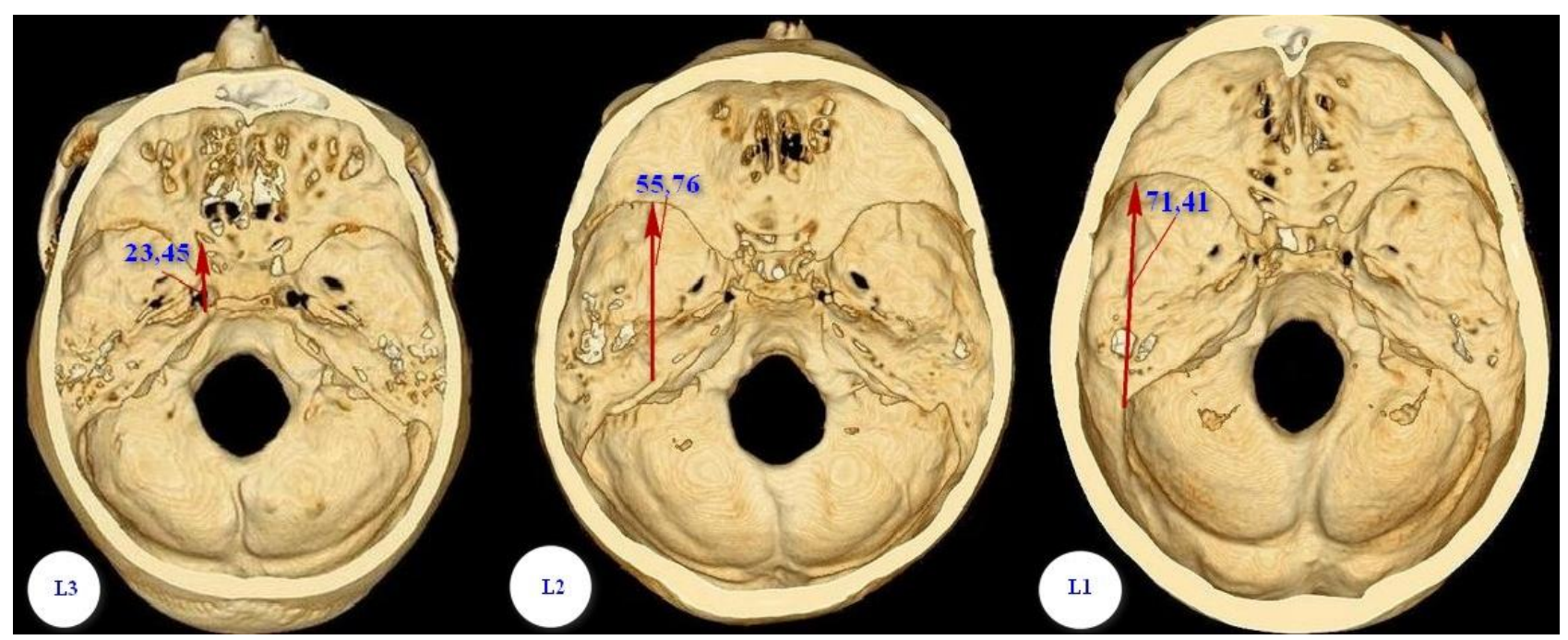

Fig. 2. The mean values of the longitudinal linear dimensions of the MCF on CT scans of the head in mature men (mm).

$\bar{x} \pm \sigma=56.28 \pm 4.57 \mathrm{~mm}$, respectively. At the same time, in the right parts of the studied area of the skull of the same age period, the size of $L_{2}$ decreases slightly: $\bar{x} \pm \sigma=$ $53.34 \pm 4.82 \mathrm{~mm}$ in men and $\bar{x} \pm \sigma=53.50 \pm 4.48 \mathrm{~mm}$ in women.

According to the obtained data, the length of the medial parts of the left and right halves of the MCF in males reaches $\bar{x} \pm \sigma=23.45 \pm 2.31 \mathrm{~mm}$ and $\bar{x} \pm \sigma=23.77 \pm 2.51 \mathrm{~mm}$, respectively. While in females this size is characterized by slightly smaller values, namely: $\bar{x} \pm \sigma=22.26 \pm 2.64 \mathrm{~mm}$ on the left and $\bar{x} \pm \sigma=22.33 \pm 2.95 \mathrm{~mm}$ on the right.

From the above data, an increase in the longitudinal dimensions of the MCF from the lateral to the medial (Fig. 2), which in our opinion is associated with the characteristic shape of this part of the skull.

The performed morphometry of the longitudinal parameters of the MCF showed that in women of mature age there is a decrease in all sizes in contrast to men (Fig. 3).

According to our data, it was found that left-sided asymmetry is observed in the study of the lateral length of the MCF in males. When determining the parameters of the length of both sexes of mature age, in addition to the above, we found the predominance of the size of the right half over the left. This suggests a right-sided asymmetry of the MCF of mature persons. These values are confirmed by statistical indicators.

In parallel, to detail the craniometric characteristics of the MCF, a number of transverse parameters at different levels in adults of both sexes were studied (Table 2).

The total width of the MCF through the center of the ST $\left(A_{1}\right)$ in male and female of mature age is $\bar{x} \pm \sigma=121.42 \pm 5.34$ $\mathrm{mm}$ and $\bar{x} \pm \sigma=116.69 \pm 5.48 \mathrm{~mm}$. In mature males, the transverse total size at the level of the ST tubercle is $\bar{x} \pm \sigma=$ $119.55 \pm 7.12 \mathrm{~mm}$ and in women $-\bar{x} \pm \sigma=114.41 \pm 7.06 \mathrm{~mm}$.

According to our data, the anterior width $\left(a_{1}\right)$ of the left and right halves of the MCF has a certain range of variability depending on sex: in males it is $\bar{x} \pm \sigma=40.97 \pm 3.33 \mathrm{~mm}$ and $\bar{x} \pm \sigma=41.71 \pm 3.21 \mathrm{~mm}$, respectively; in mature women it reaches $\bar{x} \pm \sigma=39.71 \pm 2.74 \mathrm{~mm}$ from the left side and $\bar{x} \pm \sigma=40.29 \pm 3.47 \mathrm{~mm}$ from the right part of the study area.

According to the obtained data, the transverse size $a_{2}$ in mature males ranges from $\bar{x} \pm \sigma=47.81 \pm 3.59 \mathrm{~mm}$ from the left and $\bar{x} \pm \sigma=48.94 \pm 3.15 \mathrm{~mm}$ from the right parts of the MCF, while in women the same size takes slightly smaller values: $\bar{x} \pm \sigma=45.70 \pm 3.53 \mathrm{~mm}$ (left) and $\bar{x} \pm \sigma=$ $46.48 \pm 3.53 \mathrm{~mm}$ (right).

It was found that the width of the posterior part of the MCF, as in the previous transverse parameters, tends to increase in values in males and decrease in females. Thus, from the left half of the MCF, the size from the back of the ST to the opposite point of the lateral wall of the skull reaches $\bar{x} \pm \sigma=52.13 \pm 4.02 \mathrm{~mm}$ in men and $\bar{x} \pm \sigma=50.48 \pm 3.86 \mathrm{~mm}$
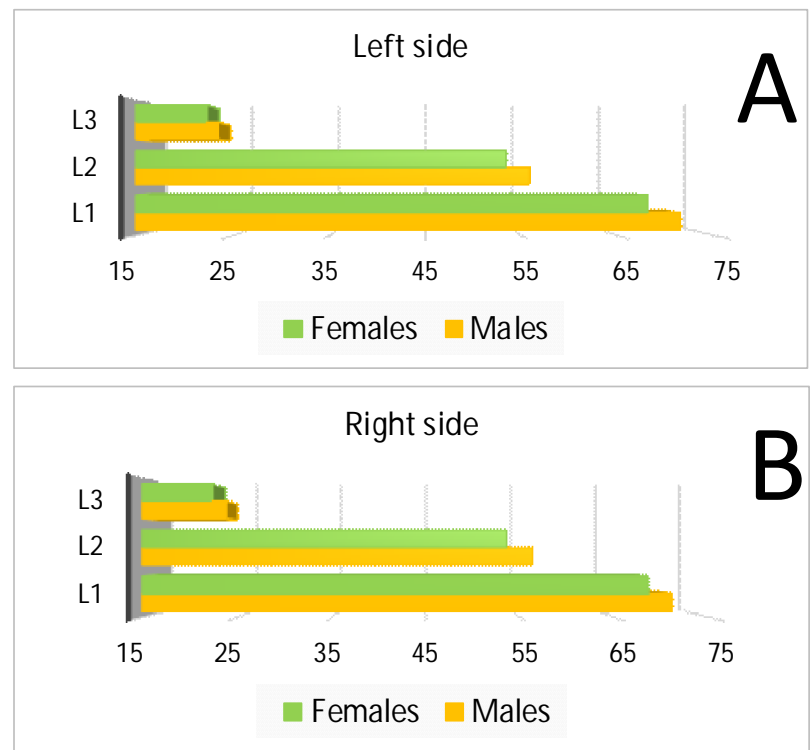

Fig. 3. The range of longitudinal MCF sizes of the skull of a mature human depending on sex $(\mathrm{mm})$ : A - left half of the MCF; B - right half of the MCF. 
Table 2. Variation and statistical indicators of the transverse dimensions of the MCF in mature persons $(\mathrm{mm})$.

\begin{tabular}{|c|c|c|c|c|c|c|}
\hline \multicolumn{2}{|c|}{ Investigated signs } & $\min$ & $\max$ & $\bar{x}$ & $\sigma$ & $\mathrm{m}$ \\
\hline \multicolumn{7}{|c|}{ Width $A_{1}$} \\
\hline \multicolumn{2}{|l|}{ Men } & 112.0 & 134.0 & 121.42 & 5.34 & 0.77 \\
\hline \multicolumn{2}{|l|}{ Women } & 105.0 & 127.0 & $116.69^{*}$ & 5.48 & 0.77 \\
\hline \multicolumn{7}{|c|}{ Width $\mathrm{A}_{2}$} \\
\hline \multicolumn{2}{|l|}{ Men } & 106.1 & 133.9 & 119.55 & 7.12 & 1.42 \\
\hline \multicolumn{2}{|l|}{ Women } & 102.4 & 124.2 & $114.41^{\star \star}$ & 7.06 & 1.41 \\
\hline \multicolumn{7}{|c|}{ Width $\mathrm{a}_{1}$} \\
\hline \multirow{2}{*}{ Left } & Men & 34.0 & 49.3 & 40.97 & 3.33 & 0.49 \\
\hline & Women & 34.7 & 46.0 & $39.71^{\star *}$ & 2.74 & 0.40 \\
\hline \multirow{2}{*}{ Right } & Men & 35.0 & 49.0 & 41.71 & 3.21 & 0.48 \\
\hline & Women & 35.0 & 51.3 & $40.29^{* *}$ & 3.47 & 0.50 \\
\hline \multicolumn{7}{|c|}{ Width $\mathrm{a}_{2}$} \\
\hline \multirow{2}{*}{ Left } & Men & 42.0 & 54.8 & 47.81 & 3.59 & 0.72 \\
\hline & Women & 39.2 & 52.2 & $45.70^{\star *}$ & 3.53 & 0.71 \\
\hline \multirow{2}{*}{ Right } & Men & 42.1 & 54.6 & 48.94 & 3.15 & 0.63 \\
\hline & Women & 39.1 & 51.1 & $46.48^{\star *}$ & 3.53 & 0.71 \\
\hline \multicolumn{7}{|c|}{ Width $\mathrm{a}_{3}$} \\
\hline \multirow{2}{*}{ Left } & Men & 44.0 & 59.0 & 52.13 & 4.02 & 0.57 \\
\hline & Women & 42.0 & 58.0 & $50.48^{\star *}$ & 3.86 & 0.54 \\
\hline \multirow{2}{*}{ Right } & Men & 46.0 & 59.2 & 53.29 & 2.91 & 0.42 \\
\hline & Women & 43.0 & 62.0 & $51.40^{*}$ & 3.68 & 0.52 \\
\hline
\end{tabular}

Notes: *- a significant difference compared to men at $p<0,01$; ${ }^{*}$ - a significant difference compared to men at $p<0,05$.

in women; on the right, $\bar{x} \pm \sigma=53.29 \pm 2.91 \mathrm{~mm}$ and $\bar{x} \pm \sigma=$ $51.40 \pm 3.68 \mathrm{~mm}$, respectively. For modern craniology, the transverse size of a3 is of great importance in determining the transverse-longitudinal and depth-transverse indices of the studied area of the skull.

According to the obtained data, the transverse dimensions of the MCF take smaller values in its anterior parts and gradually increase to the posterior ones (Fig. 4).

It should be noted that these parameters are predominant in males in contrast to females, which is due to the slightly increased head size in this group of adults (Fig. 5).

During the morphometric analysis of the transverse linear dimensions of individual sections of the MCF, it was determined that there is a slight difference between its left and right divisions. Thus, it was found that the anterior width, the width from the tubercle of the ST to the side wall of the skull and the posterior width of the right part of the specified area of IBS take greater values than the left in both sexes.

Depth parameters, which are used in the calculations of the depth-transverse index of the MCF, acquire a certain value (Table 3).

From the data in Table 3 it is clear that the depth in the male from the left half of the MCF does not exceed $\bar{x} \pm \sigma=$ $21.23 \pm 3.44 \mathrm{~mm}$ and from the right half reaches $\bar{x} \pm \sigma=$ $21.69 \pm 3.01 \mathrm{~mm}$. Women of the same age period are characterized by slightly smaller values of $\bar{x} \pm \sigma=$ $19.99 \pm 2.66 \mathrm{~mm}$ (left) and $\bar{x} \pm \sigma=20.49 \pm 2.89 \mathrm{~mm}$ (right).

According to the above, the size of the depth of the MCF has the smallest range of variability depending on sex (Fig. 6).

In parallel, there is a right-sided asymmetry of this parameter of the studied area of IBS in both sexes of mature age.

Additionally, measurements of the total area of the MCF and the area of both its departments were performed (Table 4).

Thus, in adults the total area of the entire MCF in men is $\bar{x} \pm \sigma=57.40 \pm 6.13 \mathrm{~cm}^{2}$ and in women $-\bar{x} \pm \sigma=51.49 \pm$ $4.95 \mathrm{~cm}^{2}$. In this case, the area of the left part of the left ventricle in males and females is equal to $\bar{x} \pm \sigma=27.53 \pm$ $3.31 \mathrm{~cm}^{2}$ and $\bar{x} \pm \sigma=24.49 \pm 2.58 \mathrm{~cm}^{2}$, respectively. The right part of the studied area of the skull is characterized by slightly smaller values of this parameter $\bar{x} \pm \sigma=27.69 \pm$

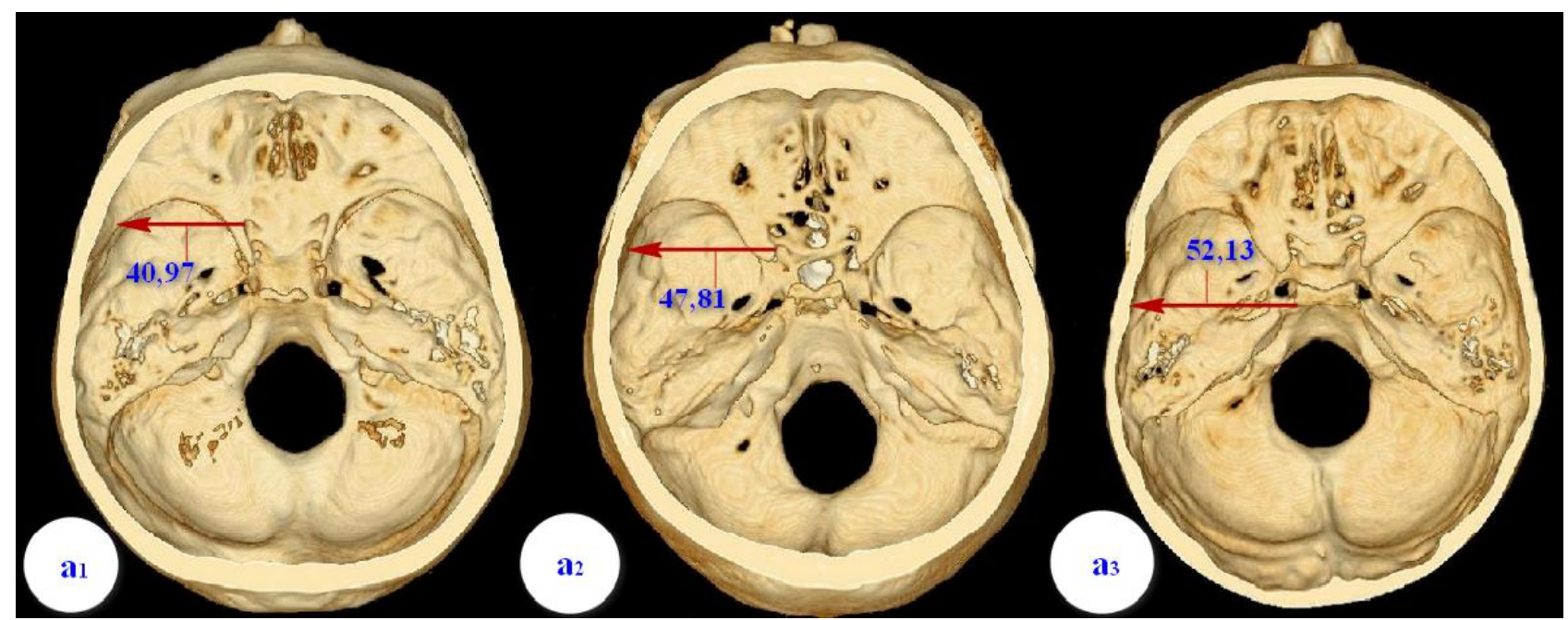

Fig. 4. The average values of the transverse dimensions of the MCF on CT scans of the head in mature men ( $\mathrm{mm})$. 


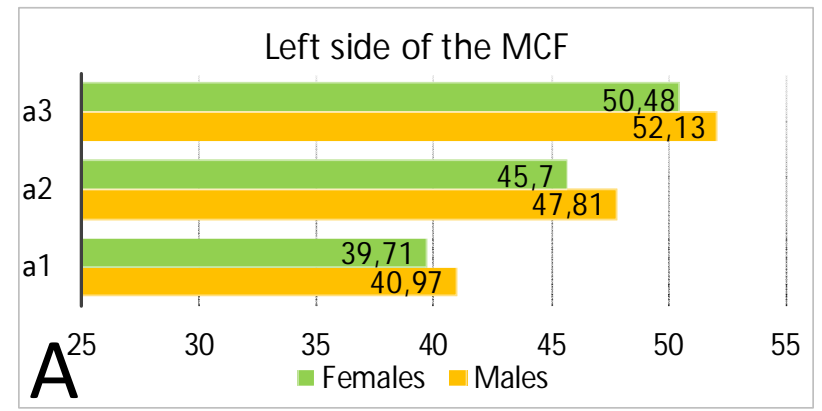

Right side of the MCF

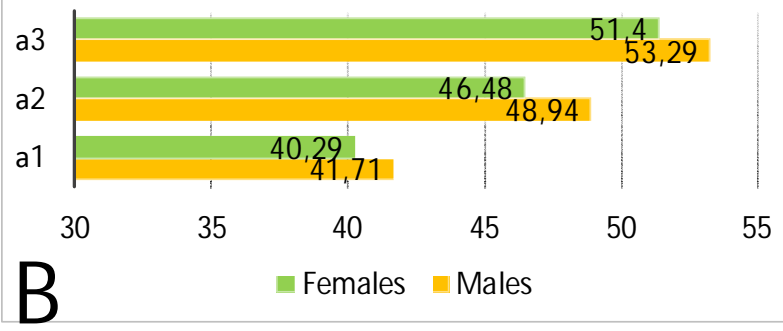

\section{The total transverse dimensions of the MCF}

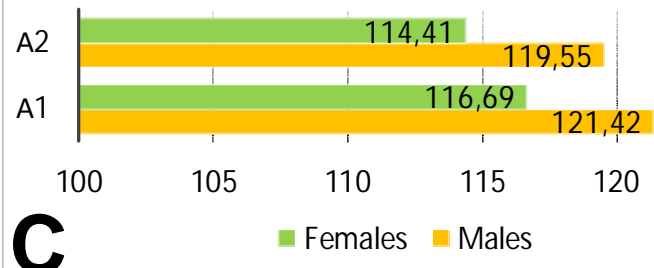

Fig. 5. Graphical display of transverse craniometric parameters of MCF depending on sex: A - transverse parameters from the left half of the MCF; B - transverse parameters from the right half of the MCF; C - general width parameters.

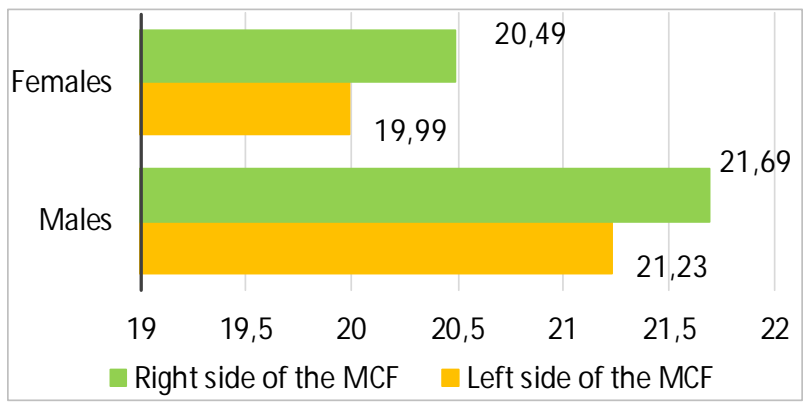

Fig. 6. Graphical display of depth on both sides of the MCF depending on sex.

\section{$2.89 \mathrm{~cm}^{2}$ (men) and $\bar{x} \pm \sigma=25.06 \pm 2.75 \mathrm{~cm}^{2}$ (women).}

According to our data, the total area and the area of the left and right parts of the MCF are characterized by a gradual increase from female to male of mature age, which is quite similar to the previously similar values of variability of linear parameters of the MCF depending on sex. Similarly to most of the determined linear parameters of the study of the inner base of the skull, when determining the area of both
Table 3. Variation and statistical indicators of size and depth of MCF in mature persons $(\mathrm{mm})$.

\begin{tabular}{|c|c|c|c|c|c|c|}
\hline \multicolumn{2}{|c|}{ Investigated signs } & $\min$ & $\max$ & $\overline{\mathrm{x}}$ & $\sigma$ & $\mathrm{m}$ \\
\hline \multirow{2}{*}{$\begin{array}{c}\text { Depth of the left half } \\
\text { of the MCF }\end{array}$} & Men & 14.0 & 27.5 & 21.23 & 3.44 & 0.49 \\
\cline { 2 - 7 } & Women & 13.0 & 27.5 & 19.99 & 2.66 & 0.37 \\
\hline \multirow{2}{*}{$\begin{array}{c}\text { Depth of the right half } \\
\text { of the MCF }\end{array}$} & Men & 16.0 & 27.3 & 21.69 & 3.01 & 0.43 \\
\cline { 2 - 7 } & Women & 12.0 & 25.0 & 20.49 & 2.89 & 0.41 \\
\hline
\end{tabular}

Table 4. Statistical indicators of MCF area in men and women $\left(\mathrm{cm}^{2}\right)$.

\begin{tabular}{|c|c|c|c|c|c|c|}
\hline \multicolumn{2}{|c|}{ Investigated signs } & $\min$ & $\max$ & $\overline{\mathrm{x}}$ & $\sigma$ & $\mathrm{m}$ \\
\hline \multirow{2}{*}{$\begin{array}{c}\text { The area of the left } \\
\text { half of the MCF }\end{array}$} & Men & 19.99 & 33.22 & 27.53 & 3.31 & 0.66 \\
\cline { 2 - 7 } & Women. & 19.82 & 29.15 & $24.49^{*}$ & 2.58 & 0.52 \\
\hline $\begin{array}{c}\text { The area of the } \\
\text { right half of the } \\
\text { MCF }\end{array}$ & Men & 20.81 & 62.67 & 27.69 & 2.89 & 0.58 \\
\cline { 2 - 7 } & Women & 19.46 & 28.99 & $25.06^{*}$ & 2.75 & 0.55 \\
\hline $\begin{array}{c}\text { The area of the } \\
\text { entire MCF }\end{array}$ & Men & 42.85 & 68.71 & 57.40 & 6.13 & 1.23 \\
\cline { 2 - 7 } & Women & 41.16 & 58.53 & $51.49^{*}$ & 4.95 & 0.99 \\
\hline
\end{tabular}

Notes: ${ }^{*}$ - a significant difference compared to men at $p<0.01$.

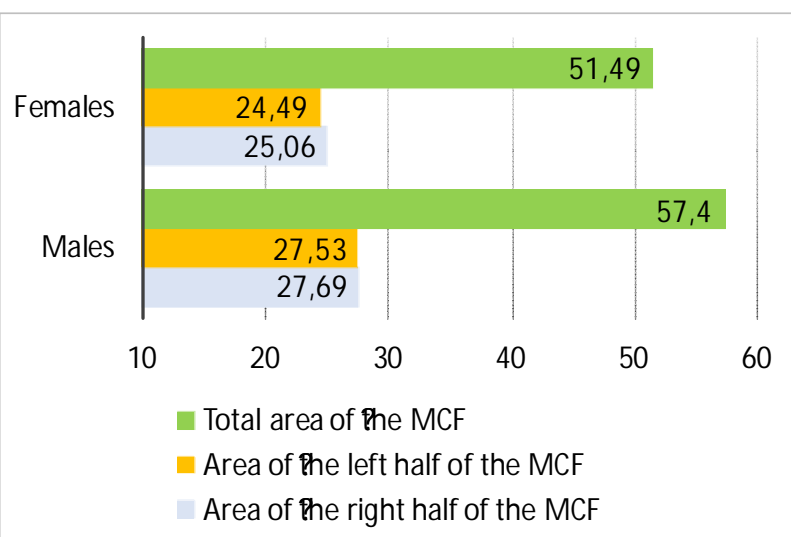

Fig. 7. The range of variability of the MCF plane as a whole and its individual parts depending on sex.

parts of the MCF, their asymmetry was revealed with the predominance of the values of this parameter in the right departments (Fig. 7).

\section{Discussion}

A small number of works are devoted to the general characteristics of the structure, shape and size of the central part of the IBS, in which different methods of determining the length, width, depth and area of the MCF are used [1, 3, $7,12,13]$.

For the first time we conducted research not only on bone preparations of the skull of a mature person, but also on CT images of the head. Given the rather complex shape of the skull, which was studied, linear parameters were measured at different levels of the MCF and from both its departments in men and women of mature age.

The study of sexual differences in longitudinal, transverse parameters and depth dimensions showed that these dimensions in males predominate over females, 
which coincides with the data of other authors who found that men have larger linear MCF dimensions than women $[3,12]$.

According to the results of our study, the presence of right-sided asymmetry of the studied parameters of the MCF of both sexes mature persons was determined. J. Lang (1982) in his study also noted the predominance of the size of the lateral parts of this area of the IBS on the right rather than on the left [13]. V.G. Koveshnikov (1959), on the contrary, noted that there is no significant difference between the sizes of the left and right halves of the MCF [12].

At the same time, we determined that the posterior parts of the MCF predominate over the anterior and lateral over the medial ones, which, in our opinion, is due to the characteristic shape of this part of the IBS.

The results of the study can further contribute to a better interpretation of craniotomograms, which will improve the diagnosis of pathological conditions within this area of the skull. Based on this study, it becomes possible to improve existing and develop new methods of surgical interventions.

\section{References}

[1] Aleshkina, O. U., Anisimov, A. N., Bukreeva, E. G., \& Khurchak, U. A. (2011). Interrelationship of middle cranial fossa parameters and dimensional characteristics of human cerebral cranium in various craniotypes. Saratov Journal of Medical Scientific Research, 7(4), 757-760.

[2] Alzhrani, G., Shelton, C., \& Coudwell, W. T. (2017). Middle fossa approach for resection of vestibular shwannoma. Acta Neurochir (Wien), 159(6), 1023-1026. doi: 10.1007/s00701017-3169-1

[3] Artemieva, V. I. (1971). Morphology and topometry of the lateral parts of the middle cranial fossa in children. Proceedings of the Saratov Medical Institute, 92, 31-39.

[4] Azab, W. A., Almanabri, M., \& Yosef, W. (2017). Endoscopic treatment of middle fossa arachnoid cysts. Acta Neurochir (Wien), 159(12), 2313-2317. doi: 10.1007/s00701-017-3320-z

[5] Bekelis, K., Moses, Z., Missios, S., Saunders, J., \& Erkmen, K. (2012). Middle cranial fossa approach: pathologies and complications. J. Neurol. Surg. B., 73, A209. doi: 10.1055/s0032-1312257

[6] Cherkasov, V. G., \& Kravchuk, S. Yu. (2018). Anatomy of man. Vinnytsia: Nova Knyha.

[7] Doronina, G. A., Gayvoronsky, A. I., \& Sherbak, A. U. (2003). Cranioscopic characteristic interernal base of skull adult people. SPb.

[8] Erbagci, H., Kizilkan, N., Sirikci, A., Yigiter, R., \& Aksamoglu, M. (2010). Computed tomography based measurement of the dimensions of foramen ovale and rotundum in trigeminal neuralgia. Neurosciences (Riyadh, Saudi Arabia), 15(2), 101104.

[9] Huang, B., Yao, M., Feng, Z., Guo, J., Zereshki, A., Leong, M., \& Qian, X. (2014). CT-guided percutaneous infrazygomatic radiofrequency neurolysis through foramen rotundum to treat V2 trigeminal neuralgia. Pain medicine (Malden, Mass.), 15(8), 1418-1428. https://doi.org/10.1111/pme.12440

[10] Johanis, M., Yang, I., \& Gopen, Q. (2018). Incidence of intraoperative hearing loss during middle cranial fossa approach for repair of superior semicircular canal dehiscence. J. Clin. Neurosci., 54, 109-112. doi: 10.1016/j.jocn.2018.06.023
The obtained data allow to expand the knowledge about the structure of MCF and can serve as a basis for further development.

\section{Conclusions}

1. The performed morphometric analysis showed the presence of a wide range of longitudinal, transverse and depth parameters of the MCF with their characteristic predominance in males.

2. The study found that the morphometric parameters of the length of the study area gradually increase from its medial to lateral, as well as from anterior to posterior departments.

3. The maximum values have the length of the lateral sections, the width of each half at the level of the back of the ST.

4. At mature people of both sexes the right asymmetry is more often noted. Rarely, left-sided asymmetry is determined by increasing the length of the lateral part in mature men.

[11] Kosty, J. A., Stevens, S. M., Gozal, Y. M., DiNapoli, V. A., Patel, S. K., Golub, J. S. ... Samy, R. N. (2019). Middle Fossa Approach for Resection of Vestibular Schwannomas: A Decade of Experience. Operative Neurosurgery, 16(2), 147-158. https:/ /doi.org/10.1093/ons/opy126

[12] Koveshnikov, V. G. (1959). Materials for the surgical anatomy of the middle cranial fossa. Saratov Medical University, 24, 149-158.

[13] Lang, J., \& Gotzfried, H. P. (1982). On the practical-medical mean distances of the fossa cranialis media. Anatomischer Anzeiger, 151(5), 433-453.

[14] Lipschitz, N., Kohlberg, G. D., Zuccarello, M., \& Samy, R. N. (2018). Comprehensive review of the extended middle cranial fossa approach. Curr. Opin. Otolaryngol. Head Neck Surg., 26(5), 286-292. doi: 10.1097/MOO.0000000000000471

[15] Lyunkova, R. N., \& Krylov, V. V. (2015). The skull base triangles. Part 1. Russian Journal of Neurosurgery, 3, 54-61. https:// doi.org/10.17650/1683-3295-2015-0-3-54-61

[16] Lyun'Kova, R. N., \& Krylov, V. V. (2015). The skull base triangles (Part 2). Russian J. of Neurosurgery, 4, 64-70. https://doi.org/ 10.17650/1683-3295-2015-0-4-64-70

[17] Maina, R., Ducati, A., \& Lanzino, G. (2007). The middle cranial fossa: morphometric study and surgical considerations. Skull Base, 17(6), 395-403. doi: 10.1055/s-2007-991117

[18] Makhambayev, G. D., Kauynbekova, Sh. M., \& Akhanov, G. Zh. (2013). Minimum invasive accesses at surgery of the basis of the lobby and average cranial pole. Herald of Almaty State Institute of Advanced Medical Education. 1, 25-26.

[19] Matsukawa, H., Fujii, M., Murakata, A., Shinoda, M., \& Takahashi, O. (2015). Foramen spinosum and middle meningeal artery in moyamoya disease: Preliminary results of a pilot study. Brain Injury, 29(10), 1246-1251. https://doi.org/10.3109/ 02699052.2015 .1035333

[20] Peng, K. A., Lecovic, G. P., \& Wilkinson, E. P. (2018). Pearls for the middle fossa approach in acoustic neuroma surgery. Curr. Opin. Otolaryngol. Head Neck. Surg., 26(5), 276-279. doi: 10.1097/moo.0000000000000479

[21] Raheja, A., Bowers, C. A., MacDonald, J. D., Shelton, C., Gurgel, 
R. K., Brimley, C., \& Couldwell, W. T. (2016). Middle Fossa Approach for Vestibular Schwannoma: Good Hearing and Facial Nerve Outcomes with Low Morbidity. World Neurosurgery, 92, 37-46. https://doi.org/10.1016/ j.wneu.2016.04.085

[22] Scheich, M., Ehrmann-Muller, D., Shehata-Dieler, W., \& Hagen, R. (2017) Hearing results after middle fossa removal of small (T1/T2) vestibular schwannomas. HNO, 65(9), 751-757. doi: 10.1007/s00106-016-0228-5

[23] Sonmez, S., Sahin, B., Polat, B., Comoglu, S., \& Orhan, K. S. (2017). Repair of Tegmen Tympani Defect Presenting with Spontaneous Cerebrospinal Fluid Otorrhea Using the Middle Cranial Fossa Approach. The Journal of International Advanced Otology, 13(3), 430-433. https://doi.org/10.5152/ iao.2017.3386
[24] Tripathi, M., Deo, R.C., Suri, A., Srivastav, V., Baby, B., Kumar, S. ... Lalwani, S. (2015). Quantitative analysis of the Kawase versus the modified Dolenc-Kawase approach for middle cranial fossa lesions with variable anteroposterior extension. J. Neurosurg., 123(1), 14-22. doi: 10.3171/2015.2.JNS132876

[25] Vovk, Yu. N. (2010). Clinical Anatomy of the Head. Lugansk: Elton-2.

[26] Xue, T., Yang, W., Guo, Y., Yuan, W., Dai, J., \& Zhao, Z. (2015). 3D Image-Guided Percutaneous Radiofrequency Thermocoagulation of the Maxillary Branch of the Trigeminal Nerve Through Foramen Rotundum for the Treatment of Trigeminal Neuralgia. Medicine, 94(45), 19-54. https://doi.org/ 10.1097/MD.0000000000001954

\section{ЗАГАЛЬНА КРАНІОМЕТРИЧНА ХАРАКТЕРИСТИКА ЛІНІЙНИХ ПАРАМЕТРІВ СЕРЕДНЬОЇ ЧЕРЕПНОЇ ЯМКИ ЛЮДИНИ ЗРІЛОГО ВІКУ \\ Чеканова І.В., Вовк О.Ю., Ікрамов В.Б., Дубина С.О.}

3 огляду на стрімкий розвиток неврології, нейрохірургії, отоларингології та судової медицини виникає потреба нових, уточнених морфологічних даних внутрішньої основи черепа, зокрема середньої черепної ямки (Счя). Це обумовлено складною кістковою архітектурою Счя та розташуванням у цій ділянці важливих судинно-нервових структур, які важливо хірургам під час операції не пошкодити. У зв'язку з цим, необхідна сучасна деталізація особливостей будови, фоорми, положення та розмірів СчЯ. Метою роботи є детальне морфологічне та краніометричне дослідження лінійних параметрів СчЯ людини зрілого віку в залежності від статі. Дослідження виконано за допомогою вивчення 50 КТ знімків голови та 50 кісткових препаратів черепів чоловіків та жінок зрілого віку. В нашому дослідженні проведена детальна морфометрія поздовжніх та поперечних параметрів на різних рівнях СчЯ, а також визначення її глибини та площі. Морфометрія лінійних параметрів досліджуваної ділянки черепа показала наявність діапазону мінливості розмірів довжини, ширини та глибини в залежності від cmami людини зрілого віку. Проведене дослідження показало збільшення поздовжніх розмірів Счя від латеральних відділів до медіальних; поперечні розміри Счя приймають менші значення у передніх її відділах та поступово збільшуються до задніх. За нашою думкою, це пов'язано з характерною формою цієї ділянки черепа. Проведена морфометрія поздовжніх та поперечних параметрів, глибини та площі СчЯ показала, що зазначені параметри переважають у чоловіків порівняно з жінками, що пов'язано з дещо збільщеним розміром голови у цієї групи людей зрілого віку. Глибина Счя має найменший діапазон мінливості в залежності від статі. Встановлено, що у зрілих людей обох статей частіше відмічається правобічна асиметрія. Досить рідко визначається лівобічна асиметрія за рахунок збільшення довжини латерального відділу у чоловіків зрілого віку. Отримані дані дозволяють розширити знання щодо будови СЧя та можуть слугувати основою до подальщих досліджень.

Ключові слова: краніометрія, зрілий вік, внутрішня основа черепа, середня черепна ямка. 